\title{
The role of cerebral oximetry monitoring in off-pump coronary artery bypass surgery of Moyamoya disease
}

\author{
Atan kalpte koroner arter bypass cerrahisi yapılan Moyamoya hastalığında \\ serebral oksimetre monitörizasyonunun yeri
}

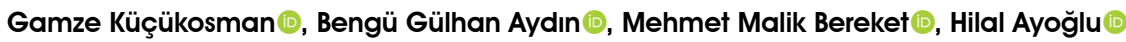

Department of Anesthesiology and Reanimation, Medicine Faculty of Bülent Ecevit University, Zonguldak, Turkey

\begin{abstract}
Moyamoya disease is a chronic cerebrovascular disease characterized by the development of compensatory collateral vessels due to progressive narrowing or obstruction of the intracranial arteries. Neurological complications after coronary bypass in patients with Moyamoya disease may be prevented by recent technical developments, surgical modifications, and cerebral monitorization. The objective of perioperative anesthetic management is to provide balance between oxygen supply and consumption of the brain. In this case report, we aim to share our anesthetic experience in a patient with Moyamoya disease who underwent off-pump coronary artery bypass surgery and cerebral oximetry monitoring.
\end{abstract}

Keywords: Anesthesia management; cerebral oxygenation monitoring; Moyamoya disease.

Moyamoya disease (MMD) is a chronic cerebral circulatory disease of unknown etiology, characterized by the development of compensatory collateral vessels as a result of bilateral progressive stenosis or occlusion of the main arteries of the Willis polygon. ${ }^{[1,2]}$ Reticular anastomosis and collaterals between internal and external carotid arteries lead to a typical "puff of smoke" appearance at angiography, described by the Japanese expression, "Moyamoya". ${ }^{[2]}$ Its incidence is high during the first decade of life and among females, and current findings suggest a familial susceptibility. ${ }^{[3]}$ While focal motor and sensory loss are observed in children due to transient ischemic attacks, intracranial hemorrhage and cerebrovascular insufficiency are observed in adults. ${ }^{[2,4]}$

\section{$\ddot{O} Z$}

Moyamoya hastalığ tıkanması sonucu kompansatuvar kollateral damarların gelişmesi ile kendini gösteren kronik serebrovasküler bir hastalıktır. Moyamoya hastalarının koroner arter bypass cerrahisi sonrası nörolojik komplikasyonları son yıllardaki teknik gelişmeler, cerrahi modifikasyonlar ve serebral monitörizasyon ile önlenebilir. Perioperatif anestezi yönetimindeki hedef beyin oksijen sunumu ve kullanımı arasındaki dengenin sağlanmasıdır. $\mathrm{Bu}$ olgu sunumunda serebral oksimetre monitörizasyonu uyguladığımız, atan kalpte koroner arter bypass cerrahisi yapılan Moyamoya hastasındaki anestezi deneyimimizi paylaşmayı amaçladik.

Anahtar sözcükler: Anestezi yönetimi; serebral oksijen monitörizasyonu; Moyamoya hastalı̆ 1 .

The objective of anesthesia in MMD is to preserve the balance between oxygen supply and consumption of the brain. Hypocapnia, hypercapnia, hypotension, and hypovolemia are significant risk factors for cerebral ischemia and should be avoided in order to prevent neurological morbidity in MMD ${ }^{[1,4]}$ Therefore, monitoring tissue and organ perfusion is quite important. Monitoring of cerebral tissue oxygen saturation with near infrared spectroscopy (NIRS) is a noninvasive method, which enables evaluation of real time hemodynamics and oxygenation. ${ }^{[3]}$ Moyamoya disease patients who have undergone revascularization surgery frequently undergo different operations. ${ }^{[5]}$ Patients with MMD who require coronary artery surgery carry the risk for perioperative cerebral ischemia. Off-pump

Received: September 07, 2017 Accepted: February 06, 2018

Correspondence: Gamze Küçükosman, MD. Bülent Ecevit Üniversitesi Tıp Fakültesi, Anesteziyoloji ve Reanimasyon Anabilim Dalı, 67600 Esenköy, Kozlu, Zonguldak, Turkey. Tel: +90372 - 2612383 e-mail: gamzebeu@gmail.com 
coronary artery bypass grafting (OPCAB) may reduce this risk compared to conventional coronary artery bypass grafting $(\mathrm{CABG})^{[6]}$ In this case, we aim to share our anesthesia experience in an MMD patient who had undergone OPCAB and cerebral oxygenation monitoring.

\section{CASE REPORT}

A 53-year-old male presented to our hospital with chest pain. Coronary angiography showed two-vessel disease and MMD was diagnosed when preparing the patient for CABG. The patient had coronary artery disease, hypertension, type 2 diabetes mellitus, and a family history of death due to cerebral artery stenosis. His physical examination was unremarkable and preoperative blood test results were within normal limits. Doppler examination revealed $100 \%$ obstruction in the right internal carotid and the left vertebral arteries, and coronary angiography revealed $100 \%$ obstruction in the left anterior descending artery (LAD) and an obstruction of the circumflex artery optus marginalis. The operation was planned using off-pump technique considering cardiopulmonary bypass and MMD-related cerebral ischemia risk.

In addition to standard monitorization of the patient, bilateral regional cerebral tissue oxygenation $\left(\mathrm{rSO}_{2}\right)\left(\mathrm{O}_{3}\right.$ [TM] Masimo Irvine, CA, USA) and bispectral index (BIS) monitoring was performed. Anesthesia maintenance was provided with balanced anesthesia with NIRS and BIS values to be within normal ranges. During the perioperative period, heart rate, mean arterial pressure, end-tidal carbon dioxide, and body temperature were kept within normal limits. On follow-up of the serial arterial blood gases, arterial carbon-dioxide pressure $\left(\mathrm{PaCO}_{2}\right)$ was measured to be between $35-42 \mathrm{mmHg}$ and oxygen pressure between $80-115 \mathrm{mmHg}$. The mean $\mathrm{rSO}_{2}$ values were measured to be between $76-82 \%$ before bypass, $72-78 \%$ during the bypass, and $75-80 \%$ after bypass. Coronary bypass was performed to LAD and the optus marginalis branch of the circumflex artery. No neurological sequela developed and the patient was discharged from the hospital seven days after surgery.

\section{DISCUSSION}

Although MMD is usually limited within the intracranial space, it sometimes involves extracranial arteries such as the renal or the coronary artery. ${ }^{[7]}$ In the literature, MMD-related coronary artery stenosis has been reported in only 12 cases. Only three of these patients underwent coronary artery surgery and of these, single vessel surgery was performed in only one patient who was a 56-year-old Japanese woman. ${ }^{[8,9]}$

The anesthesia method that should be selected for MMD patients is controversial. The main points that should be considered include continuity of cerebral blood flow, maintenance of intracranial pressure within normal ranges, and prevention of ischemic brain injury regardless of the selected method. ${ }^{[1]}$ Balanced and total intravenous anesthesia is reported to be the proper method in revascularization surgery in MMD patients. ${ }^{[10]}$ Carbon dioxide is a potent regulator of cerebral vascular tonus, and the cerebral blood flow decreases in response to hypocarbia. In MMD, hypocarbia is reported to potentiate cerebral ischemia to a higher extent and to be an important risk factor for stroke; hypercapnia is reported to lead to cerebral ischemia by diverting blood from the collateral circulation towards normal vessels..$^{[1,11,12]}$ Normocarbia is significant in providing optimal cerebral supply. ${ }^{[13]}$ Kim and $\mathrm{Yoo}^{[6]}$ reported that they preferred the OPCAB method for maintaining blood $\mathrm{PaCO}_{2}$ level within normal ranges and avoiding the risk of intraoperative hypotension in an MMD case. Similarly, $\mathrm{PaCO}_{2}$ was maintained between $35-42 \mathrm{mmHg}$, and no postoperative complications were encountered through balancing the potential hemodynamic changes by preferring a balanced anesthesia method and the OPCAB method.

Cerebral oxygen monitoring with NIRS during cardiovascular surgery is a widely accepted method with gradually increasing value. ${ }^{[14]}$ Near infrared spectroscopy monitoring is suggested to be rather useful for patients who are at high risk for neurological complications during cardiac surgery. ${ }^{[15]}$ Goldman et al. ${ }^{[16]}$ investigated the follow-up of some of the 1,297 patients who had undergone CABG with or without NIRS, and found the stroke rate to be lower in patients who had been followed-up with NIRS during the postoperative 18 months. They reported that cerebral $\mathrm{rSO}_{2}$ decreased when tissue oxygenation was impaired due to hypotension, hemodilution, anemia, catheter malposition during the intraoperative period, and improved when appropriate measures were taken. ${ }^{[14,17]}$ The Murkin treatment protocol can be used as an effective tool to prevent cerebral desaturation during CABG. ${ }^{[18]}$ In our case, no decreases in the hematocrit that might have adversely affected cerebral oxygenation were observed during the perioperative period. The body temperatures of patients in the OPCAB did not change significantly, while the mean nasopharyngeal temperature decreased to $35.9-36.4^{\circ} \mathrm{C}$. Maintenance of appropriate intraoperative ventilation and adequate gas perfusion during $\mathrm{OPCAB}$, as well 
as monitoring and management of blood gas levels, allowed the blood gas values to be maintained within the reference ranges. Therefore, development of hypoxia, hyperoxia, hypocapnia, hypercapnia, and their unfavorable outcomes could be avoided. During OPCAB procedures, the heart rate and blood pressure are iatrogenically lowered to facilitate application of distal anastomoses. Short-term controlled hypotension does not result in serious hemodynamic changes or adverse outcomes. The mean blood pressure during application of the distal anastomoses was between 60 and $100 \mathrm{mmHg}$.

In conclusion, regional cerebral tissue oxygenation monitoring with near infrared spectroscopy has positive effects on postoperative neurological complications in Moyamoya disease patients who have undergone offpump coronary artery bypass grafting. We believe that cerebral oxygen monitoring plays a significant role for early recognition and prevention of complications that could arise as a result of occlusions in the right internal carotid artery and left vertebral arteries.

\section{Declaration of conflicting interests}

The authors declared no conflicts of interest with respect to the authorship and/or publication of this article.

\section{Funding}

The authors received no financial support for the research and/or authorship of this article.

\section{REFERENCES}

1. Baykan N, Ozgen S, Ustalar ZS, Dagçinar A, Ozek MM. Moyamoya disease and anesthesia. Paediatr Anaesth 2005; 15:1111-5.

2. Suzuki J, Takaku A. Cerebrovascular "moyamoya" disease. Disease showing abnormal net-like vessels in base of brain. Arch Neurol 1969;20:288-99.

3. Andropoulos DB, Stayer SA, Diaz LK, Ramamoorthy C. Neurological monitoring for congenital heart surgery. Anesth Analg 2004;99:1365-75.

4. Bingham RM, Wilkinson DJ. Anaesthetic management in Moya-moya disease. Anaesthesia 1985;40:1198-202.

5. Jimi N, Shin T. Anesthetic management of a patient with Moyamoya disease undergoing open heart surgery. Paediatr
Anaesth 2006;16:1195-6.

6. Kim DK, Yoo KJ. Off-pump coronary artery bypass grafting in moyamoya disease. Yonsei Med J 2007;48:876-8.

7. Halley SE, White WB, Ramsby GR, Voytovich AE. Renovascular hypertension in moyamoya syndrome. Therapeutic response to percutaneous transluminal angioplasty. Am J Hypertens 1988;1:348-52.

8. Komiyama M, Nishikawa M, Yasui T, Otsuka M, Haze K. Moyamoya disease and coronary artery disease--case report. Neurol Med Chir (Tokyo) 2001;41:37-41.

9. Komiyama M, Ishikawa T, Takanashi S, Shimizu Y. Minimal invasive direct coronary artery bypass in moyamoya disease. Interact Cardiovasc Thorac Surg 2003;2:65-7.

10. Adachi K, Yamamoto Y, Kameyama E, Suzuki H, Horinouchi T. Early postoperative complications in patients with Moyamoya disease--a comparison of inhaled anesthesia with total intravenous anesthesia (TIVA). Masui 2005;54:653-7. [Abstract]

11. Baaj AA, Agazzi S, Sayed ZA, Toledo M, Spetzler RF, van Loveren H. Surgical management of moyamoya disease: a review. Neurosurg Focus 2009;26:E7.

12. Soriano SG, Sethna NF, Scott RM. Anesthetic management of children with moyamoya syndrome. Anesth Analg 1993;77:1066-70.

13. Sato K, Shirane R, Yoshimoto T. Perioperative factors related to the development of ischemic complications in patients with moyamoya disease. Childs Nerv Syst 1997;13:68-72.

14. Zheng F, Sheinberg R, Yee MS, Ono M, Zheng Y, Hogue CW. Cerebral near-infrared spectroscopy monitoring and neurologic outcomes in adult cardiac surgery patients: a systematic review. Anesth Analg 2013;116:663-76.

15. Gazioğlu Türkyılmaz G, Karadeniz Ü, Demir ZA, Kemerci P, Koçulu R, Bindal M, et al. Monitorisation of cerebral oxygenation in cardiac surgeries with and without cardiotomy. GKDA Derg 2017;23:8-14.

16. Goldman S, Sutter F, Ferdinand F, Trace C. Optimizing intraoperative cerebral oxygen delivery using noninvasive cerebral oximetry decreases the incidence of stroke for cardiac surgical patients. Heart Surg Forum 2004;7:E376-81.

17. Demir ZA, Karadeniz Ü, Dönmez A, Aydınlı B, Paç A, Paç $\mathrm{M}$, et al. An evaluation of bilateral cerebral oxygen saturation during cyanotic and non-cyanotic cardiac surgery. Turk Gogus Kalp Dama 2016;24:619-26.

18. Murkin JM, Adams SJ, Novick RJ, Quantz M, Bainbridge D, Iglesias I, et al. Monitoring brain oxygen saturation during coronary bypass surgery: a randomized, prospective study. Anesth Analg 2007;104:51-8. 